\title{
Heifers rearing on natural grassland under rotational grazing during warm season
}

\section{Luciana Marin ${ }^{1 *}$ Fernando Luiz Ferreira de Quadros ${ }^{1}$ (D) Leandro Bittencourt de Oliveira $^{2}$ (D) Émerson Mendes Soares $^{3}$ (D) Pedro Trindade Casanova ${ }^{1}$ (D) Pedro Luiz do Nascimento ${ }^{1}$ (D)}

${ }^{1}$ Laboratório de Ecologia de Pastagens Naturais (LEPAN), Departamento de Zootecnia, Universidade Federal de Santa Maria (UFSM), $97150-900$, Santa Maria, RS, Brasil. E-mail: lumarin.zoot@gmail.com. *Corresponding author.

${ }^{2}$ Universidade Regional Integrada do Alto Uruguai e das Missões (URI), Frederico Westphalen e Santo Ângelo, RS, Brasil.

${ }^{3}$ DSM Nutritional Products, São Paulo, SP, Brasil.

ABSTRACT: This study aimed to evaluate the effect of two rest intervals between grazing on the structural characteristics of pasture and performance of beef heifers in Campos grassland under rotational grazing. The treatments were two intervals between 375 and 750 DD (degree-days) grazing, based on the cumulative thermal sum for leaf expansion of native grasses belonging to capture and conservation groups of resources dominant in a natural grassland. The experiment was conducted during 151 days from October 2015 to March 2016, and twentyfour Braford heifers tests mean age $=12$ months; mean body weight $=220 \mathrm{~kg}( \pm 27.8)$ were used. The pre-grazing total forage mass (FMt) was on average $3791 \mathrm{kgMSha}^{-1}$ and did not differ between treatments and season, the same occurred with the non-tussock FM. The average stocking rate was $469 \mathrm{~kg} \mathrm{ha}^{-1}$ in both treatments. The average daily gain varied only between seasons, $0.102 \mathrm{~kg}^{\text {animal }} \mathrm{l}^{-1}$ day-1 during spring and 0.372 $\mathrm{kg}_{\text {animal }} \mathrm{l}^{-1}$ day ${ }^{-1}$ during summer. During the 151 evaluation days, the gain per area was a $103 \mathrm{kgha}^{-1}$. The use of rest intervals between grazing based on the leaf elongation of dominant grasses, when applied to the areas of Campos grasslands, provided nutritional conditions to reach the target body weight for breeding 24 months old beef heifers.

Key words: Pampa biome, grassland, animal production.

Recria de novilhas em pastagem natural sob pastoreio rotativo na primavera-verão

RESUMO: $O$ estudo objetivou avaliar o efeito de dois intervalos de descanso entre pastoreios nas características estruturais do pasto e desempenho de novilhas de corte em pastagens naturais manejadas em pastejo rotativo. Os tratamentos foram dois intervalos entre pastejos de 375 e 750 GD (graus dia), baseados na soma térmica da duração de elongação foliar média de gramíneas de grupos de captura e conservação dos recursos dominantes de uma pastagem natural. O experimento foi conduzido no periodo de outubro de 2015 a março de 2016 , com duração de 151 dias e os periodos experimentais divididos em primavera e verão. Foram utilizadas 24 novilhas teste da raça Braford, com idade inicial na média de 12 meses, e de peso corporal médio de $220 \mathrm{~kg}$ ( $\pm 27,8)$. A Massa de forragem total (FMt) pré-pastejo foi em média de $3791 \mathrm{kgMSha}^{-1}$ e não diferiu entre tratamentos e estação, o mesmo ocorreu com a FM de estrato não touceira. A taxa de lotação média foi de $469 \mathrm{kgha}^{-1}$ em ambos os tratamentos. O ganho médio diário variou apenas entre estações, com médias de 0,102 $\mathrm{kganimal}^{-1}$ dia ${ }^{-1}$ na primavera e 0,372 $\mathrm{kganimal}^{-1}$ dia $^{-1}$ no verão. O ganho por área durante os 151 dias de avaliação foi em média de $103 \mathrm{kgha}^{-1}$. As pastagens naturais submetidas a intervalos de descanso entre pastoreios baseados na elongação foliar de gramineas dominantes, independente do tratamento utilizado, proporcionam ritmos de ganhos médios diários compativeis com a meta de peso corporal, a ser atingida aos 24 meses, para que as novilhas possam ser acasaladas.

Palavras-chave: bioma Pampa, campo nativo, produção animal.

\section{INTRODUCTION}

Grasslands are the predominant potential vegetation in Rio Grande do Sul and contain a great diversity of species. It is known that between 70 and $80 \%$ of the biomass is composed of grasses (GUIDO et al. 2016). Cruz et al., (2010) aiming to simplify management, proposed the construction of a typology of grasslands based on leaf attributes that could meet management criteria demanded by producers and technicians. Native grasses were thus classified into four functional groups (A, B, C, and D) according to leaf attributes such as specific leaf area and dry matter content. Groups A and B are composed of grasses characteristic of resource capture, represented mainly by Axonopus affinis and Paspalum notatum, while groups $\mathrm{C}$ and $\mathrm{D}$ are composed of grasses from resource conservation, such as Aristida laevis and Saccharum trinii (MACHADO et al., 2013).

Grasslands are often considered poorly productive mainly because of the lack of knowledge on their adequate management, which generates 
low reproductive performance of bovine herds, with low birth rates and low pregnancy recurrence rates, especially in primiparous females. The base of the breeding herd structure, which is female rearing, ends up being marginalized in most of the properties because it does not generate economic return immediately. According to Nabinger et al. (2009); although, grasslands have a lower support capacity when compared to cultivated pastures, they are still the most economical way to produce beef cattle in this region of the country, provided they are properly managed. Thus, it is necessary to seek alternatives to increase production rates and enable a better use of the natural forage resource.

The use of rest intervals between pastures is one of the alternatives related both to the physiological mechanisms of the plants and to the productive parameters of the pasture. Many studies have been proposed, and some have indicated a greater capacity to support grasslands of rotational grazing (BRISKE et al., 2008). In rotational grazing, the rest interval defines the frequency of defoliation, and the intensity of grazing (load, stocking, etc.) defines the intensity of defoliation, which can directly affect the individual performance of the animals (PEDREIRA, 2011; SILVA e NASCIMENTO JUNIOR, 2007).

Leaf elongation duration (LED) is a new criterion for defining the grass rest interval. It considers that leaf laminas (leaf) in elongation are the most efficient in terms of photosynthesis, maintaining their nutritional value high both in $\mathrm{C} 3$ and $\mathrm{C} 4$ species (CONFORTIN et al., 2010; QUADROS et al., 2011). Based on the thermal sum of the LED of dominant grass groups Barbieri et al., (2014) and Soares et al., (2015), this study aimed to evaluate the performance of heifers managed in a grassland under rotational grazing with two rest intervals between grazing.

\section{MATERIALS AND METHODS}

The experiment was conducted in an experimental area of the Department of Animal Science of the Federal University of Santa Maria, located in the Central Depression of the Rio Grande do Sul State, with geographical coordinates $29^{\circ} 43^{\prime} \mathrm{S}, 53^{\circ} 42^{\prime} \mathrm{W}$ and an altitude of $95 \mathrm{~m}$ above sea level. Treatments were two different pasture rest intervals considering as rest the mean LED of the two functional types of grasses: resource capture (functional groups A and B) and resource conservation (functional groups $\mathrm{C}$ and $\mathrm{D}$ ) (acoording to the functional grouping of CRUZ et al., 2010).

Treatments were rest intervals of 375 and 750 degree-days (DD) between grazing. The 375
DD treatment was based on the thermal sum of the mean elongation of two and a half leaves of grasses from groups A and B (Axonopus affinis, Paspalum notatum). The 750 DD treatment was based on the elongation of one and a half leaves of groups grasses from C and D (Aristida laevis, Saccharum trinii) (MACHADO et al., 2013). The occupation period of each paddock was defined by dividing the accumulated thermal sum of each treatment by the number of resting paddocks of each experimental unit. Daily mean temperatures were obtained from the INMET website (Figure 1).

Treatments were arranged in an experimental area of 22.5 hectares in a randomized block design with three replicates. The blocking criterion was the position in the relief, which comprised hilltops, hillslopes, and foot slopes. Each block was divided into sets of experimental units (paddocks), one with seven and the other with eight subdivisions (for the 375 and 750 DD treatments, respectively) of approximately 0.5 ha per subdivision.

The experimental period was 151 days, from October 23, 2015 to March 22, 2016, and periods were divided into seasons. Spring season were considered from October 23, 2015 to December 21, 2015 and summer season from December 22, 2015 to March 22, 2016. Twenty-four Braford test heifers with an initial mean age of 12 months and a mean body weight of $220 \mathrm{~kg}( \pm 27.8)$ were used. The animals were preferably distributed so that each experimental unit received four test animals.

The pasture was under rotational grazing with variable stocking rate. A variable number of animals of the same category and sex, with a mean weight of $189( \pm 26) \mathrm{kg}$, was used for adjusting the stocking rate. The mean stocking rate (MSR) was obtained by dividing the ISR by the total area of each experimental unit of each treatment. The animal stocking rate was adjusted for the consumption of $70 \%$ of the leaf mass greater than $1000 \mathrm{~kg} \mathrm{ha}^{-1}$ during the occupation of each paddock. The following equation, which considers a forage disappearance of $4.5 \%$ of body weight (BW) (HERINGER \& CARVALHO, 2002), was used for adjusting the instantaneous animal stocking (ISR $=\mathrm{kg}$ of live weight $/$ ha in the occupied paddock):

$\mathrm{ISR}=\left((\text { TotalFM-1000 })^{*}\left(\%\right.\right.$ green leaves $\left.\left.{ }^{*} 0.7\right)\right) / 0.045 / 2 /$ number of days of occupation (3 or 5).

Forage mass (FM) was determined using the visual estimation technique by comparing standards, and it was calibrated using the double sampling proposed by Haydock and Shaw (1975). Each of the subdivisions (6) of the treatment was 


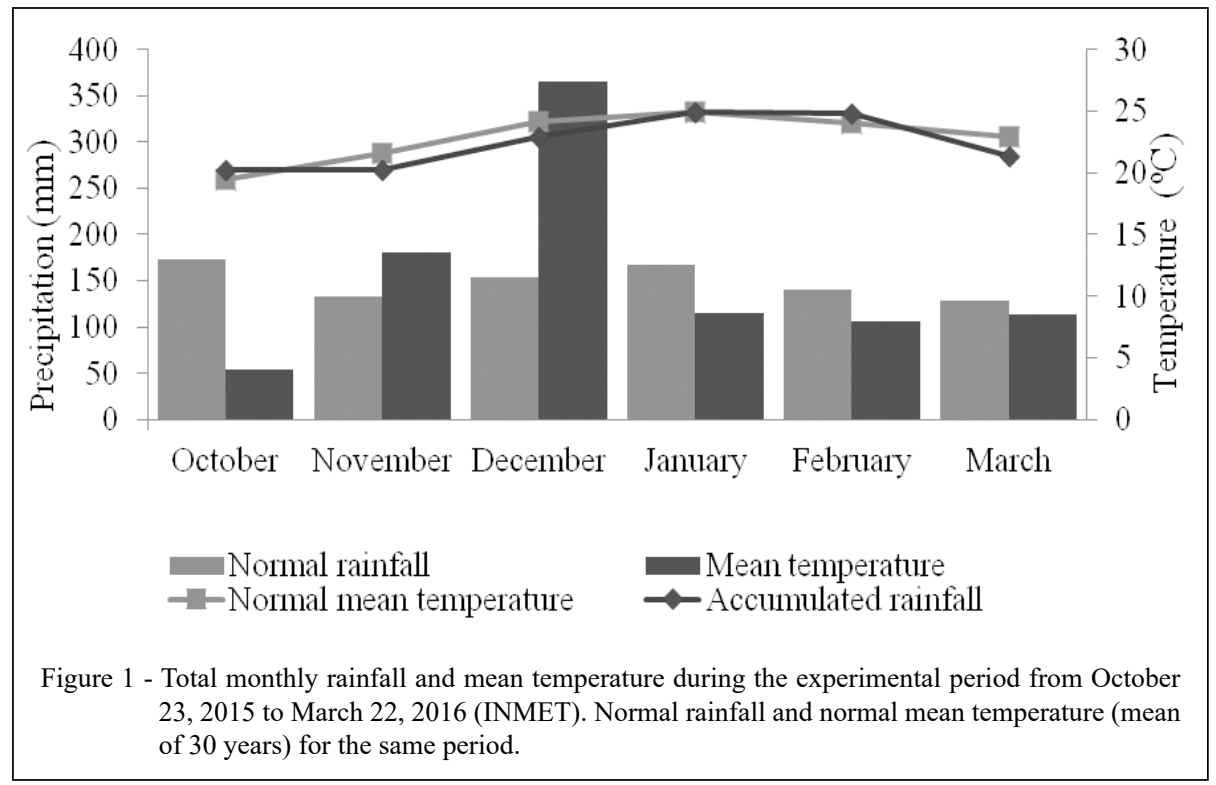

evaluated in the blocks with 30 visual estimates and 10 sections using a metal frame with an area of 0.25 $\mathrm{m}^{2}$. In each of the tables of the 30 estimates, three canopy heights were measured using a graduated ruler (in $\mathrm{cm}$ ), and the structures were classified as tussock and non-tussock. Density was obtained by dividing the forage mass by the average height of each strata.

From the ten cuts made, three representative samples of the evaluated subdivision were chosen; these samples were sent for botanical and structural separation, in which the leaf and stems/grass roots, dead material (in senescence), and other non-grasses species present in the vegetation were separated. To determine the dry matter (DM) of the sample, the other cuts were taken to the oven with forced air circulation at $60{ }^{\circ} \mathrm{C}$ until they reached constant weights.

In order to estimate the post- grazing FM and disappearance of the forage, after the animals had left the representative subdivisions, six cuts were made in the stratum without tussock in order to collect the representative samples. Samples were dried in oven with forced air circulation until reaching constant weight and were used in the calculation of the output FM. The difference of the disappeared forage was obtained by subtracting the output FM from the input FM of the lower layer of the pasture. The disappearance rate was calculated from the difference in FM divided by the instantaneous stocking rate and by the mean number of days of occupation of each representative subdivision.

The mean daily weight gain (MDG) was obtained by the difference of the animal's weight among the weightings, divided by the day number among the weightings. Animals had a 12 hours total fasting period approximately each 28 days.

Live weight gain (LWG) per hectare (in $\mathrm{kg} \mathrm{ha}^{-1}$ ) was obtained by dividing the MSR by the mean weight of the test animals in each sample unit multiplied by the MDG of the test animals and by the number of days of the experiment (151 days). These values were subjected to analysis of variance and $F$ test. The analysis of variance was performed using the Proc GLM procedure of the SAS ${ }^{\circledR}$ University Edition software (2016), with the inclusion of the effects of block, treatment, season, and treatment $\times$ season interaction into the model. The means were compared with LSMEANS considering a 5\% significance level. The results were tested for normality.

\section{RESULTS AND DISCUSSION}

There was no interaction between treatments and periods for the variables related to pre-grazing forage mass (Table 1). The mean pasture height of the 750 treatment was $4.1 \mathrm{~cm}$ higher than that of the 375 treatment; a difference was observed between seasons: during the summer was higher than spring, with means of 20.8 and 21.10 , respectively. The height of the non-tussock strata was higher for the 750 treatment than the 375 treatment, with means of $15.9 \mathrm{~cm}$ and $13.9 \mathrm{~cm}$, respectively. The pasture height during the summer was $5.8 \mathrm{~cm}$ higher than during the spring season. 
Table 1 - Mean daily gain (MDG), mean stocking rate (MSR), instantaneous stocking rate (ISR), total forage allowance (FAt), non tussock forage allowance (FAnt). Pre- grazing Height, Forage mass (FM), and \% of structural components, of total biomass and non-tussock stratum (NT) in a natural grassland managed with rotational grazing method with two rest intervals (375 and 750 degree-day; DD).

\begin{tabular}{|c|c|c|c|c|c|c|c|c|c|}
\hline \multirow[t]{2}{*}{ Variables } & \multirow[t]{2}{*}{ Units } & \multicolumn{2}{|c|}{---Treatments--- } & \multicolumn{2}{|c|}{--------Seasons------ } & \multicolumn{4}{|c|}{-------Significance level (P)------- } \\
\hline & & 375 & 750 & Spring & Summer & Treatments & Seasons & $\mathrm{TxS}$ & $\mathrm{CV}$ \\
\hline MDG & $\mathrm{kg} \mathrm{an}^{-1}$ day $^{-1}$ & 0.198 & 0.276 & 0.102 & 0.372 & 0.323 & 0.002 & 0.638 & 77.93 \\
\hline MSR & $\mathrm{kg} \mathrm{ha}^{-1}$ & 474.0 & 465.0 & 516.1 & 423.8 & 0.802 & 0.161 & 0.206 & 20.89 \\
\hline ISR & $\mathrm{kg} \mathrm{ha}^{-1}$ & 1738 & 1777 & 1928 & 1586 & 0.766 & 0.014 & 0.156 & \\
\hline FAt & $\%$ & 7.6 & 8.9 & 8.1 & 8.4 & 0.415 & 0.588 & 0.119 & 19.07 \\
\hline FAnt & $\%$ & 5.0 & 5.6 & 5.0 & 5.7 & 0.151 & 0.113 & 0.633 & 20.69 \\
\hline Height & $\mathrm{cm}$ & 18.90 & 23.39 & 20.82 & 21.1 & 0.001 & 0.002 & 0.523 & 15.56 \\
\hline FM & $\mathrm{kg} \mathrm{ha}^{-1}$ & 3485 & 4098 & 4083 & 3500 & 0.070 & 0.085 & 0.604 & 23.35 \\
\hline Leaf blade & $\%$ & 0.36 & 0.36 & 0.31 & 0.41 & 0.830 & 0.0002 & 0.548 & 15.82 \\
\hline Stem & $\%$ & 0.07 & 0.06 & 0.05 & 0.07 & 0.374 & 0.001 & 0.332 & 38.79 \\
\hline Dead material & $\%$ & 0.49 & 0.51 & 0.59 & 0.41 & 0.426 & $<0.0001$ & 0.795 & 23.73 \\
\hline Height (NT) & $\mathrm{cm}$ & 13.9 & 15.97 & 12.00 & 17.84 & 0.036 & $<0.0001$ & 0.112 & 16.25 \\
\hline FM (NT) & $\%$ & 2310 & 2520 & 2484 & 2346 & 0.209 & 0.405 & 0.122 & 18.17 \\
\hline Leaf blade (NT) & $\%$ & 0.41 & 0.45 & 0.37 & 0.5 & 0.229 & 0.0004 & 0.291 & 18.70 \\
\hline Stem (NT) & $\%$ & 0.06 & 0.07 & 0.05 & 0.07 & 0.846 & 0.137 & 0.077 & 53.27 \\
\hline $\begin{array}{l}\text { Dead material } \\
(\mathrm{NT})\end{array}$ & $\%$ & 0.43 & 0.39 & 0.51 & 0.31 & 0.226 & $<0.0001$ & 0.107 & 26.11 \\
\hline
\end{tabular}

The total FM (3791. $\mathrm{kg} \mathrm{ha}^{-1}$ ) was similar between treatment and seasons. Similarly, the FM of the non-tussock strata did not show any difference between treatments and seasons, with mean of $2415 \mathrm{~kg} \mathrm{ha}^{-1}$. The frequency of tussocks was similar between treatments $(\mathrm{P}=0.774)$, with a mean of $41 \%$ and $42 \%$ of tussocks present in the 375 and 750 treatments, respectively.

Density of pre-grazing forage mass was similar between treatments $(\mathrm{P}=0.8000)$ for both strata, with an average of $183 \mathrm{~kg} \mathrm{~cm}^{-1} \mathrm{ha}^{-1}$ and $171.5 \mathrm{~kg} \mathrm{~cm}^{-1}$ $\mathrm{ha}^{-1}$ in the total forage mass and non-tussock strata, respectively. However, as the pasture height, it was different between the evaluated seasons $(\mathrm{P}<0.001)$. During the spring, the average density of the total forage mass was $214.5 \mathrm{~kg} \mathrm{~cm}^{-1} \mathrm{ha}^{-1}$ while, during the summer, it was $153 \mathrm{~kg} \mathrm{~cm}^{-1} \mathrm{ha}^{-1}$. In the non-tussock stratum there was a reduction from $210.6 \mathrm{~kg} \mathrm{~cm}^{-1} \mathrm{ha}^{-1}$ to $132.5 \mathrm{~kg} \mathrm{~cm}^{-1} \mathrm{ha}^{-1}$, from spring to the summer.

The percentage of leaf blades in the total FM increased over the seasons, starting with mean values of $31 \%$ in spring, and increasing to $41 \%$ in summer. The same occurred with the percentage of stems, which at the beginning of the experiment was $5 \%$, and during the experimental period increased gradually, reaching $7 \%$ in summer (Table 1). In contrast, the percentage of dead material in forage decreased of $59 \%$ to $41 \%$. The structural components evaluated in the non-tussock stratum had a similar behavior to the total FM throughout the experiment, with the percentage of leaves increasing from $37 \%$ in spring to $50 \%$ in summer, and the percentage of dead material decreasing from $51 \%$ to $31 \%$. However, the percentage of stems was similar between treatments and seasons, with the average value of $6,2 \%$.

The variables related to the post-grazing FM did not show any difference between seasons $(\mathrm{P}=0.5321)$. However, it was higher in the $750 \mathrm{DD}$ $\left(1436 \mathrm{~kg} \mathrm{DMha}^{-1}\right)$ than $375 \mathrm{DD}$ (1231 kg DMha$\left.{ }^{1}\right)$ The post grazing pasture height was $8.6 \mathrm{~cm}(\mathrm{P}$ $=0.0 .3752)$, for both treatments, it was different between seasons $(P=0.0001)$ increasing from $7.1 \mathrm{~cm}$ in the spring to $10.19 \mathrm{~cm}$ during the summer, the residual FM was $1307 \mathrm{~kg}$ DM.ha $^{-1}(\mathrm{P}=0.655)$. The average disappearance rate was $7 \%$ for both treatments $(\mathrm{P}=0.0615)$. The mean time of paddocks occupation was 2.8 and 4.8 days of the 375 and 750 treatments, respectively. The mean resting intervals were 19 and 37 days for the 375 and 750 treatments, respectively. While the treatment with shortest resting interval allowed 11 grazing cycles, the treatment with longest resting interval allowed 6 grazing cycles. 
The initial BW of the heifers (mean $=220$ $\mathrm{kg})$ was similar between the treatments $(\mathrm{P}=0.479)$, as well as the weight at the end of the experiment (mean $=265.5 \mathrm{~kg} ; \mathrm{P}=0.576$ ). The weight gain of the experimental period was $40 \mathrm{~kg}$ per animal. Although, MDG was $0.246 \mathrm{~kg} \mathrm{an}^{-1}$ day $^{-1}$ and showed no difference between treatments $(\mathrm{P}=0.0962)$, it was higher in the summer period $(\mathrm{P}=0.00017)$ than in the spring, with gains greater than $0.300 \mathrm{~kg} \mathrm{an}^{-1}$ day $^{-1}$. Body weight gain per area was also similar between treatments $(\mathrm{P}=0.3559)$ with a mean of $103 \mathrm{~kg} \mathrm{ha}^{-1}$.

The MSR (469 $\mathrm{kg} \mathrm{ha}^{-1}$ ) was similar between treatments and seasons $(\mathrm{P}>0.005)$. However, ISR was different between experimental periods ( $\mathrm{P}$ 0.0139), with higher values during the first period (spring) compared to the following (summer), with average values of $1928.2 \mathrm{~kg}$ and $1585.9 \mathrm{~kg}$, respectively. Total forage allowance $(\mathrm{FAt})(\%)($ mean $=8.2 \%)$ showed no difference between treatments and seasons. Nontussock forage stratum allowance (FAnt) (mean = $5.3 \%$ ) also showed no differences between treatments and seasons.

The FM observed in the present study was higher than that observed by Trindade et al. (2016) when analyzing different forage allowances $(4 \%, 8 \%$, $12 \%$, and $16 \%$ ) in a grassland of the Pampa biome. Trindade et al. (2016) reported higher forage intake rates with a forage allowance of $12 \%$ and a FM of 1820-2280 kg DM.ha ${ }^{-1}$, with a maximum percentage of tussocks of $30 \%$. The higher values observed in the present research are because of the greater percentage of tussocks in the FM. The disappearance rate of the forage $(7 \%)$ was higher than the recommended for cultivated pastures, which is $4.5 \%$ of the $\mathrm{BW}$ of the animals (HERINGER; CARVALHO, 2002).

The percentage of leaves increased over the seasons in both strata, while the percentage of senescent material decreased. This was because of the greater participation of $\mathrm{C} 4$ metabolic grasses, which have a high biomass production during the warm season and are responsible for the strong seasonal variation in production and forage quality (MODERNEL et al. 2016).

Pre-grazing height increased in the summer, where instantaneous stocking was lower than that of the first experimental period (spring). Although, the mean pre-grazing FM did not change over the seasons, the MDG was higher in the summer; this was due the increasing on pre-grazing pasture height, as well as the greater contribution of leaf blades and decrease of dead material, over this period.

The MDG found in the summer corroborated previous studies with rotational grazing in grasslands such as those of Barbieri et al. (2014) in the spring-summer period, which observed gains of approximately $0.300 \mathrm{~kg} \mathrm{an}^{-1}$ day $^{-1}$. When the results of the use of eco-physiological parameters for the rotational grazing of a grassland are compared to the conduction of continuous stocking with an allowance of $12 \%$, the MDG value reported is in accordance with the $0.324 \mathrm{~kg} \mathrm{an}^{-1}$ day $^{-1}$ observed by Pinto et al. (2008) in the pasture growth season. However, these values are lower than the $0.6 \mathrm{~kg} \mathrm{an}^{-1}$ day $^{-1}$ found by Soares et al. (2005) for a continuous stocking with allowance of $12 \%$ also in a pasture of the Central Depression of Rio Grande do Sul.

The forage allowances used in this experiment were below those recommended by Maraschin (1998), who defines allowances between 11.5 and $13.5 \%$ LW as an optimal range for the use of grassland. Soca et al. (2013), analyzing brood cows, considered an allowance of $10 \%$ as high, which is a value close to those observed in the present study. However, it is important to note that pastures in Uruguay tend to have fewer structural limitations because of the lower percentage of tussocks in the total FM.

The total forage allowance over $8 \%$ in both the 375DD and 750DD treatments, were not limiting for the animals, as the desired residual FM of 1000 $\mathrm{kg} \mathrm{DM} \mathrm{ha}{ }^{-1}$ was maintained in all periods. Long-term experiments with grassland (BREMM et al., 2012) have indicated that a percentage of tussocks above $34 \%$ may limit the forage intake rate of the animals, which may lead to low mean daily gains. The mean percentage of tussocks estimated in the present experiment was $42 \%$.

The percentage of senescent material in total $\mathrm{MF}$, especially in the spring (means $=59 \%$ ) may also have been a limiting factor in the individual performance of the animals. The similarity in the gains in live weight per area observed in the treatments $\left(103 \mathrm{~kg} \mathrm{ha}^{-1}\right)$ can be explained by the similarity in FM and $\%$ of structural components of the tussock and, non-tussock stratum in both treatments.

The LWG values obtained in the present study in the experimental period can be considered satisfactory if compared with the annual mean of the State, which rarely exceeds $70 \mathrm{~kg} \mathrm{ha}^{-1}$ (CARVALHO et al., 2006). However, the values are lower than those obtained by Soares et al. (2005) and Mezzalira et al. (2012) in continuous grazing with forage allowances of $8 \%$ and $12 \%$, respectively.

It is important to emphasize that the stocking rate used in the present study reduced by less than $50 \%\left(1031 \mathrm{~kg}\right.$. ha- $\left.{ }^{-1}\right)$ the non-tussock stratum FM, which disappeared (through consumption and 
senescence) during the occupation period. Thus, it was possible to keep a mean residue of $1370 \mathrm{~kg} \mathrm{ha}^{-1}$ in the tussock stratum. This can be considered as a moderate grazing intensity, favoring the regrowth of the pasture after the animals depart. Both the rest intervals of 375 and $750 \mathrm{DD}$ ensured the expansion of the leaves. As there was probably no highly marked reduction in the proportion of leaves and the newly expanded or expanding leaves have greater photosynthetic capacity than mature leaves (PARSONS et al., 1988), the total photosynthetic capacity was not excessively affected.

Among the indicative of reproductive parameters, only the weight of the animals was measured, weight performance analysis showed that heifers gained $40 \mathrm{~kg}$ throughout the experiment. That is, they started with a mean BW of $220 \mathrm{~kg}$, and at the end they had a BW of $260 \mathrm{~kg}$. Heifers with this weight are not fit for mating because, according to PATTERSON et al. (1992), this value represents $65 \%$ of the adult weight of the breed. Considering that the adult weight of Braford females is $450 \mathrm{~kg}$, heifers would be fit for mating when they reach a mean value of $292 \mathrm{~kg}$. Thus, if the goal is to mate at 18 months of age, these animals should have gained $0.483 \mathrm{~kg}$ in the period observed. However, if the goal is to reach the target weight and mate at 24 months of age, they should have an MDG of 32 $\mathrm{kg}$ until the beginning of the mating period, that is, approximately 224 days.

\section{CONCLUSION}

The use of rotational grazing systems, based on the cumulative thermal sum for leaf expansion of native grasses belonging to capture and conservation groups with grazing intervals of 375DD or $750 \mathrm{DD}$, to manage Campos grasslands, provided nutritional conditions to reach the target body weight of $290 \mathrm{~kg}$ for breeding 24 months old beef heifers.

\section{ACKNOWLEDGEMENTS}

This work was supported by Conselho Nacional de Desenvolvimento Científico e Tecnológico (CNPq) Proc. 402968/2016-6 and partly by the Coordenação de Aperfeiçomento de Pessoal de Nível Superior (CAPES), Brasil - Finance code 001 .

\section{ETHICS AND BIOSAFETY COMMITTEE}

\section{DECLARATION OF CONFLICT OF INTERESTS}

The authors declare no conflict of interest. The founding sponsors had no role in the design of the study; in the collection, analyses, or interpretation of data; in the writing of the manuscript, and in the decision to publish the results.

\section{AUTHORS' CONTRIBUTIONS}

The authors contributed equally to the manuscript.

\section{REFERENCES}

BREMM, C. et al. Foraging behaviour of beef heifers and ewes in natural grasslands with distinct proportions of tussocks. Applied Animal Behaviour Science, v.141, p.108-116, 2012. Available from: $\quad<$ https://doi.org/10.1016/j.applanim.2012.08.008.>. Accessed: Dec. 20, 2018. doi: 10.1016/j.applanim.2012.08.008.

BARBIERI, C. W. et al. Sward structural characteristics and performance of beef heifers reared under rotational grazing management on Campos Grassland. American Journal of Plant Sciences, v.05, p.1020-1029, 2014. Available from: <.https:// www.scirp.org/journal/paperinformation. aspx?paperid=44174>. Accessed: Apr. 21, 2016. doi: 10.4236/ajps.2014.57114.

BRISKE, D. D. et al. Rotational grazing on rangelands: Reconciliation of Perception and Experimental Evidence. Rangeland Ecology and Management, v.61, p.3-17, 2008. Available from: <https:/www.sciencedirect.com/science/article/ abs/pii/S1550742408500078?via\%3Dihub>. Accessed: Mar. 10,2016. doi: 10.2111/06-159R.1.

CARVALHO, P.C.F. et al. Produção animal no bioma Campos sulinos. Brazilian Journal of Animal Science, João Pessoa, v.35, n.Supl. Esp.,p.156-202,2006. Available from: $<$ https://pdfs.semanticscholar. org/d3d2/fe1e89a6be63b10f9391b723ad9dbea2a3d1.pdf>. Accessed: Jun. 11, 2020.

CONFORTIN, A. C. C. et al. Morphogenesis and structure of Italian ryegrass submitted to three grazing intensities Acta Scientiarum. Animal Sciences, v.32, n.4, p.385-391, 2010. Available from: $<$ http://periodicos.uem.br/ojs/index.php/ActaSciAnimSci/article/ view/8657>. Accessed: Apr. 15, 2016. doi: 10.4025/actascianimsci. v32i4.8657.

CRUZ, P. et al. Leaf traits as functional descriptors of the intensity of continuous grazing in native grasslands in the south of Brazil. Rangeland, Ecology \& Management, v.63, n.3, p.350-358, 2010. Available from: <https:/www.sciencedirect.com/science/article/ abs/pii/S1550742410500289>. Accessed: Apr. 10, 2016. doi: $10.2111 / 08-016.1$

GUIDO, A. et al. Spatial and temporal variability in aboveground net primary production of uruguayan grasslands spatial and temporal variability in aboveground net primary production of uruguayan grasslands. In: Rangeland Ecology \& Management v.67, n.1, p.30-38, 2014. Available from: <https://www.sciencedirect.com/ science/article/abs/pii/S1550742414500024>. Accessed: Apr. 25, 2019. doi: 10.2111/REM-D-12-00125.1

HAYDOCK, K. P.; SHAW, N. H. The comparative yield method for estimating dry matter yield of pasture. Australian Journal 
of Experimental Agriculture and Animal Husbandry, cap.15, p.663-670, 1975. Available from: <http://usi.earth.ac.cr/glas/ sp/50000138.pdf>. Accessed: Apr. 02, 2016.

HERINGER, I.; CARVALHO, P. C. D. F. Stocking rate adjustment in grazing experiments: a new approach Ciência Rural, v.32, p.675-679, 2002. Available from: <https://www.scielo.br/scielo. php? script $=$ sci_arttext\&pid=S0103-84782002000400021> Accessed: Jun. 12, 2017. doi: 10.1590/S0103-84782002000400021.

Instituto Nacional de Meteorologia (INMET). Available from: $<$ http://www.inmet.gov.br/portal/Andgt $>$.

MACHADO, J. M.; ROCHA, M. G.; QUADROS, F. L. F. et al. Morphogenesis of native grasses of Pampa Biome under nitrogen fertilization. Revista Brasileira de Zootecnia, v.42, n.1, p.22-29, 2013. Available from: <https://www.scielo.br/ scielo.php?script=sci_arttext\&pid=S1516-35982013000100004>. Accessed:Mar. 17,2017.doi:10.1590/S1516-35982013000100004.

MARASCHIN, G.E. Manejo de pastagens nativas, produtividade animal e dinâmica da vegetação em pastagens nativas do Rio Grande do Sul. In: Reunião do Grupo Técnico em Forrageiras do Cone Sul - Zona Campos, 17., 1998, Lages. Anais. Lages: Epagri/ UDESC, 1998. p. 47-54

MEZZALIRA, J. C. et al. Produção animal e vegetal em pastagem nativa manejada sob diferentes ofertas de forragem por bovinos. Ciência Rural, v.42, n.7, p.1264-1270, 2012. Available from: $<$ https://www.scielo.br/scielo.php?pid=S0103$84782012000700021 \&$ script $=$ sci abstract\&tlng $=$ pt $>$. Accessed: Oct. 25 , 2018. doi: 10.1590/S0103-84782012005000039.

MODERNEL, P. et al. Land use change and ecosystem service provision in Pampas and Campos grasslands of southern South America. Environmental Research Letters, 11, 113002. 2016. Available from: <https://ui.adsabs.harvard.edu/ abs/2016ERL....11k3002M/abstract>. Accessed: Apr. 29. 2018. doi: $10.1088 / 1748-9326 / 11 / 11 / 113002$

PARSONS, A. J.; et al.. Use of a model to optimize the interaction between frequency and severity of intermittent defoliation to provide a fundamental comparison of the continuous and intermittent defoliation of grass. Grass and Forage Science, Oxford, v.43, n.1, p.49-59, 1988. doi: 10.1111/j.1365-2494.1988. tb02140.x.

PATTERSON, D. J.;et al. Management considerations in heifer development and puberty. Journal Animal Science, v.70, n.12, p.4018-4035, 1992. Available from: <https://www.sciencedirect. com/science/article/abs/pii/S0749072013000662?via\%3Dihub>. Accessed: Apr. 15, 2016. doi: 10.1016/j.cvfa.2013.07.014.
PEDREIRA, C. G. S. Produção de forragem e o uso dos métodos de pastejo com lotação contínua e/ou lotação rotativa ou intermitente. In: CECATO, U. et al. (Ed.). Simpopasto: Simpósio de Produção Animal a Pasto. Maringá, PR: Sthampa, 2011. Cap. 6, p. 189-219.

PINTO, C. E. et al. Primary and secondary production in a natural pasture submitted to different herbage allowances at the "Depressão Central", Rio Grande do Sul. Revista Brasileira de Zootecnia, v.37, n.10, p.1737-1741, 2008. Available from: $<$ https://www.scielo.br/scielo.php?script $=$ sci_arttext\&pid $=$ S1516-35982008001000004 $>$. Accessed: May, 24, 2017. doi: $10.1590 / \mathrm{S} 1516-35982008001000004$

QUADROS, F. L. F.; et al. Utilizando a racionalidade de atributos morfogênicos para o pastoreio rotativo: experiência de manejo agroecológico em pastagens naturais do Bioma Pampa. Cadernos de Agroecologia/Revista Brasileira deAgroecologia, v.6,p.12716/7020, 2011. Available from: $<$ http://revistas.aba-agroecologia.org.br/index. $\mathrm{php} / \mathrm{cad} / \mathrm{article} / \mathrm{view} / 12716>$. Accessed: Mar. 11.2017.

SOARES, A. B. et al. Animal and forage production on native pasture under different herbage allowance. Ciência Rural, v.35, n.5, p.1148-1154, 2005. Available from: <https://www.scielo.br/ scielo.php?script $=$ sci_arttext\&pid=S0103-84782005000500025>. Accessed:Mar. 18.2016.doi: 10.1590/S0103-84782005000500025.

SILVA, S.C ; NASCIMENTO JUNIOR, D. Avanços na pesquisa com plantas forrageiras tropicais em pastagens: características morfofisiológicas e manejo do pastejo. R. Bras. Zootec., Viçosa, v.36, supl. p.122-138, July 2007 . Available from: <http://www.scielo.br/ scielo.php?script $=$ sci arttext\&pid $=$ S1516-35982007001000014\&ln $\mathrm{g}=\mathrm{en} \& \mathrm{nrm}=\mathrm{iso}>$. Accessed: Jun. 11, 2020. doi: 10.1590/S151635982007001000014.

SOARES, E. M et al. Beef heifers performance in natural grassland under continuous and rotational grazing in the autumn-winter. Ciência Rural, v.45, n.10, p.1859-1864, 2015. Available from: $<$ https:/www.scielo.br/pdf/cr/v45n10/1678-4596-cr-45-10-01859. pdf >. Accessed: Oct. 27, 2018. doi: 10.1590/0103-8478cr20141529.

SOCA, P. et al. Oferta de forraje del campo natural y resultado productivo de los sistemas de cría vacuna del Uruguay: I. Producción, uso y conservación del forraje aportado por campo natural In: QUINTANS, G.; SCARSI, A. (Eds.). Seminario de actualización técnica: cría vacuna Montevideo (UY): INIA, 2013. p. 97-117.

TRINDADE, J. K. et al. Daily forage intake by cattle on natural grassland: response to forage allowance and sward structure. Rangeland Ecology \& Management, v.69, p.59-67, 2016. Available from: $<$ https://www.sciencedirect.com/science/article/ abs/pii/S1550742415001256?via\%3Dihub>. Accessed: May, 15, 2017. doi: 10.1016/j.rama.2015.10.002. 